\title{
Isolation of the Arawete and Asurini Indians keeps the tribes free from HTLV infection during 36 years of follow-up
}

\author{
Antonio C. R. Vallinoto" ${ }^{*}$, Mateus I. Otake ${ }^{1}$, Paulo V. N. R. Sousa' ${ }^{1}$ Felipe T. Lopes ${ }^{1}$, Eliene R. P. Sacuena², \\ Maria A. F. Queiroz ${ }^{1}$, Greice L. C. Costa², Marluísa O. G. Ishak' , Izaura M. V. Cayres-Vallinoto' ${ }^{1}$, João F. Guerreiro ${ }^{2}$ \\ and Ricardo Ishak ${ }^{1}$
}

\begin{abstract}
Arawete and Asurini Indian tribes were revisited after a 36-year follow-up in search of HTLV infections. 46 persons (23 from each tribe) were tested for HTLV-1/2 antibodies and viral DNA. None were positive; this was probably because of their social/cultural isolation from neighboring tribes where HTLV-2c is hyperendemic.
\end{abstract}

Keywords: HTLV-1/2, Indian tribe, Arawete, Asurini, Amazon region

Human T-lymphotropic virus 2, a member of the family Retroviridae, has been reported as a hyperendemic infection in several Amerindian tribes since 1992, particularly in the Brazilian Amazon region, among the Kayapó villages of the Jê linguistic group [1-3]. Furthermore, studies have shown evidence of HTLV-2 circulating among other Indians from different linguistic groups in the Amazon region of Brazil [3-6], in which breastfeeding and sexual intercourse are the main transmission routes $[3,5,7,8]$. Phylogenetic and molecular analyses of the viral strain reported a new molecular subtype termed HTLV-2c, which is largely distributed in the Amazon region of Brazil [3, 4].

Since the early 1980s, native Indian tribes of the Amazon region of Brazil have been constantly receiving health support from our laboratories to monitor the spread of viruses and bacterial infections, particularly those transmitted by the sexual route. Since our initial large-scale testing [4], HTLV-1/2 have been routinely investigated to monitor their spread in both previously infected and virus-free villages. The present paper reports the maintenance of HTLV-free areas of infection among the

\footnotetext{
*Correspondence: vallinoto@me.com

1 Virus Laboratory, Institute of Biological Sciences, Federal University

of Para, Rua Augusto Corrêa No.1, Belém, Para 66075-110, Brazil

Full list of author information is available at the end of the article
}

Arawete (Igarapé Ipixuna-Médio Xingu, Para State, Brazil) and Asurini (Koatinemo-Médio Xingu, Para State, Brazil) groups belonging to the Tupí-Guarani linguistic group.

The Arawete and Asurini tribes were revisited in 2019, and again, the possibility of HTLV-1/2 emergence in their communities was monitored. The project was approved by the National Committee for Ethics in Research (CONEP), process $961.451 / 2015$. Both visits received the agreement and consent of the communities through their leaders on behalf of the participants with formal written authorization, together with the National Indian Foundation (FUNAI), to offer health support and to investigate the presence of antibodies to infectious agents.

Table 1 describes the demographic information of forty-six subjects, 18 males and 28 females, with ages ranging from 5 to 85 years old, from the Arawete $(n=23)$ and Asurini $(\mathrm{n}=23)$ tribes (Xingu region, State of Para) who were screened for anti-HTLV-1/2 antibodies by enzyme-linked immunosorbent assay (ELISA, Ortho Diagnostic, Raritan, NJ, USA). No positive or indeterminate reactions were observed. To avoid false negative results, such as those found among the Arara do Laranjal tribe [9], all the samples were submitted to a Strip Immunoblot Assay (Chiron*RIBA HTLV-I/II SIA, Johnson \& Johnson Company, Raritan, NJ, USA) and a real-time polymerase chain reaction (qPCR) to the HTLV-2-pol 
Table 1 Demographic data from the Asurini and Arawete tribes and their neighboring HTLV-2 infected Indian communities

\begin{tabular}{|c|c|c|c|c|c|c|c|}
\hline Ethnicity & $\mathbf{N}$ & Male & Age range & Female & Age range & HTLV-2 (\%) & Reference \\
\hline Arawete & 23 & 10 & 25 to 85 & 13 & 26 to 83 & 0 & * \\
\hline Asurini & 23 & 8 & 5 to 72 & 15 & 17 to 63 & 0 & $*$ \\
\hline Kayapó & 200 & 86 & 0 to $>70$ & 114 & 0 to $>70$ & 33 & 3 \\
\hline Arara Laranjal & 47 & 26 & $\mathrm{NI}$ & 21 & $\mathrm{Nl}$ & 11.4 & 3 \\
\hline Parakanã & 52 & $\mathrm{NI}$ & $\mathrm{NI}$ & $\mathrm{Nl}$ & $\mathrm{NI}$ & 1.9 & 3 \\
\hline Kararaô & 24 & 11 & $\mathrm{NI}$ & 11 & $\mathrm{NI}$ & 12.5 & 7 \\
\hline Xikrin & 257 & 146 & 2 to 90 & 111 & 2 to 90 & 29 & 8 \\
\hline
\end{tabular}

NI No information available

*Present study

gene, as previously described [8]. Immunoblot confirmed the absence of antibodies for HTLV-1/2, and qPCR confirmed the absence of HTLV-2 infection in the Arawete and Asurini tribes 36 years after their first investigation, suggesting that cultural and social isolation of these villages kept them free of the infection from other neighboring tribes where HTLV-2 is hyperendemic.

Both Indian groups, Arawete $\left(4^{\circ} 51^{\prime} \mathrm{S}\right.$ and $\left.52^{\circ} 21^{\prime} \mathrm{W}\right)$ and Asurini $\left(4^{\circ} 12^{\prime} \mathrm{S}\right.$ and $\left.52^{\circ} 26^{\prime} \mathrm{W}\right)$, reside within reservations located in the State of Para, Brazil, and are surrounded by other communities, including the Kararaô (Jê linguistic group), the Arara do Laranjal (Karib), the Parakanã (Tupi), the Xikrin do Cateté (Jê) and several Kayapó villages (Jê) living in the same reservation (Fig. 1). It is important to mention that the prevalence of HTLV-2 ranged from 1.9 to $33 \%$ within these communities in our first visits (Table 1), and the most recent investigation that revisited three Xicrin villages found a continued high

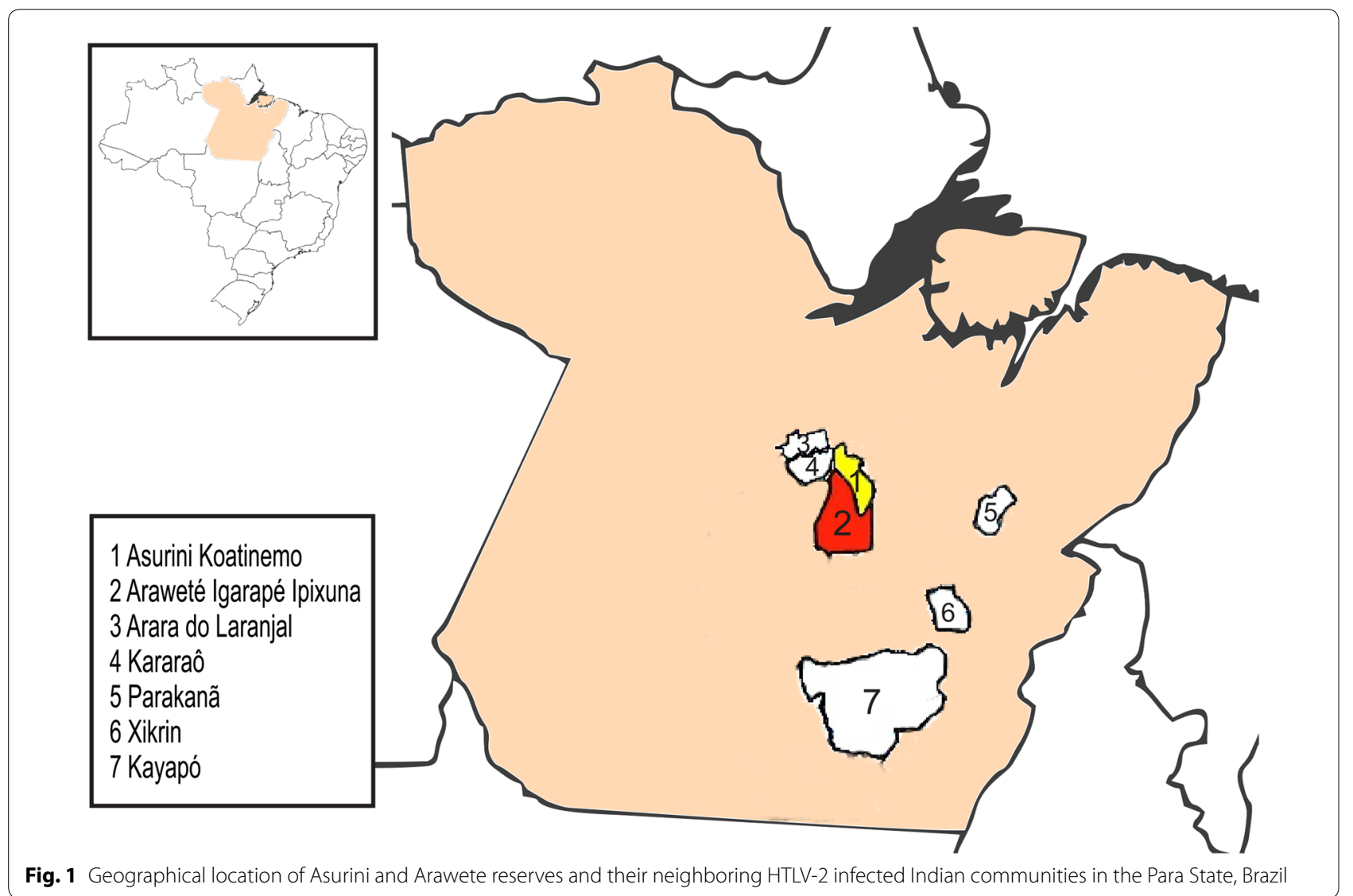


prevalence of infection [8]. Hyperendemicity of HTLV-2 among these communities is commonly sustained by sexual and mother-to-child (during pregnancy and perinatal breastfeeding) transmission [3-9]. Geographical proximity among these reservations was not an obstacle to the Asurini and Arawete villages in maintaining the cultural and social isolation during the years that prevented their interethnic mixing with neighboring Indian and nonIndian communities; their historical reports of ethnic conflicts [10] are important factors that have most likely prevented the virus from emerging among them.

The Indian populations of the Amazon region of Brazil are, to a great extent, epidemiologically closed or semiclosed communities with little or no interaction at all with other population groups, suggesting that the virus is an ancient infection among Indian populations of the Amazon region of Brazil [6]. The occurrence of HTLV-2 among distinct ethnicities is possibly associated with a typical founder effect [11], a usual demographic process that occurred during the formation of several Indian populations [12]. It is a common component of the formation of new communities during the fission of older and larger groups and new fusions to establish new communities. The founder effect reduces the presence of the virus from a stock population and, by chance, may select negative persons to establish a new smaller group. This is clearly evident when one considers the split of the Kararaô group, which was originally from the large Kayapó group of villages. Prevalence rates were down from a mean of $33 \%$ (Kayapó villages) to $12.5 \%$ (Kararaô). Infectious agents such as HTLV-2, which persistently infect the host, are maintained within familial clusters $[3,7$, 13 ] and then efficiently spread within epidemiologically closed groups via sexual and vertical routes [3-9]. The Jê linguistic group within the Kayapó and the Xikrin reservations is an aggregate of villages with more than 2000 individuals, and both kept the virus despite the chance of village formations. The population stock that gave rise to the Arawete and Asurini (both Tupi linguistic groups) did not carry the virus, and this epidemiological situation continues to the present day.

The persons investigated were 5-85 years old, which means they were born before and after the first contact in the 1980s. The sample size, although apparently small, represents approximately $20-50 \%$ of the total inhabitants of the villages. The Asurini, following their initial contact in the 1970 s, suffered a population decrease from 100 to 52 persons, mostly because of infectious diseases originally unknown to the community, and they were never able grow again due to their abortion and infanticide practices [14]. The Arawete have had constant conflicts with the Asurini and the Parakanã (also a Tupi linguistic group) since the 1970s, and the population is hardly more than 300 individuals in a single village by the Ipixuna igarapé on the right bank of the Middle Xingu [14, 15]. The Arawete maintain an ancient social habit of exchanging partners [15], which would impact the virus spread if HTLV-2 were present.

Ongoing health expeditions to Indian tribes for the last 40 years have proved successful from the viewpoints of providing health access and continuous epidemiological surveillance to prevent the spread of infectious agents including HTLV-2 among Indian communities and neighboring rural populations.

The investigation of HTLV-1/2 infection among the Arawete and Asurini Indian tribes over a follow-up of 36 years reinforces that social and cultural isolation of the villages, motivated by historical conflicts, kept them free of infection from other neighboring tribes where HTLV-2 is sometimes hyperendemic.

\section{Abbreviations}

HTLV: human T-lymphotropic virus; CONEP: National Committee for Ethics in Research; FUNAl: National Indian Foundation; ELISA: enzyme-linked immunosorbent assay; qPCR: real-time polymerase chain reaction.

\section{Acknowledgements}

Thanks to FUNAI and all participants of the Arawete and Asurini tribes.

\section{Authors' contributions}

ACRV and RI designed the study. ACRV and RI were the general coordinators of the project. MIO, PVNRS and MAFQ provided technical assistance and executed the experiments. ERPS, GLCG and JFG provided sample collection. ACRV and IMVCV analyzed all data. ACRV and RI wrote the manuscript with input from all authors. MOGI revised the manuscript. All authors read and approved the final manuscript.

\section{Funding}

This investigation was fully supported by grants from the Conselho Nacional de Desenvolvimento Científico e Tecnológico-CNPQ (Grant \#302582/2013-4) and Universidade Federal do Pará (PAPQ/2019).

Availability of data and materials

The datasets used and/or analysed during the current study are available from the corresponding author on reasonable request.

Ethics approval and consent to participate

The project was approved by the National Committee for Ethics in Research (CONEP), process 961.451/2015.

\section{Consent for publication}

Not applicable.

\section{Competing interests}

The authors declare that they have no competing interests.

\section{Author details}

${ }^{1}$ Virus Laboratory, Institute of Biological Sciences, Federal University of Para, Rua Augusto Corrêa No.1, Belém, Para 66075-1 10, Brazil. ${ }^{2}$ Human and Medical Genetics Laboratory, I Institute of Biological Sciences, Federal University of Para, Belém, Para, Brazil. 
Received: 6 October 2019 Accepted: 17 October 2019

Published online: 22 October 2019

\section{References}

1. Maloney EM, Biggar RJ, Neel JV, Taylor ME, Hahn BH, Shaw GM, et al. Endemic human T cell lymphotropic virus type II infection among isolated Brazilian Amerindians. J Infect Dis. 1992;166:100-7.

2. Black FL, Biggar RJ, Neel JV, Maloney EM, Waters DJ. Endemic transmission of HTLV type II among Kayapo Indians of Brazil. AIDS Res Hum Retroviruses. 1994;10:1165-71.

3. Ishak R, Harrington WJ Jr, Azevedo VN, Eiraku N, Ishak MO, Guerreiro JF, et al. Identification of human T cell lymphotropic virus type lla infection in the Kayapo, an indigenous population of Brazil. AIDS Res Hum Retroviruses. 1995;11:813-21.

4. Vallinoto AC, Ishak MO, Azevedo VN, Vicente AC, Otsuki K, Hall WW, et al. Molecular epidemiology of human T-lymphotropic virus type II infection in Amerindian and urban populations of the Amazon region of Brazil. Hum Biol. 2002;74:633-44.

5. Ishak R, Vallinoto AC, Azevedo VN, Ishak Mde O. Epidemiological aspects of retrovirus (HTLV) infection among Indian populations in the Amazon region of Brazil. Cad Saude Publica. 2003;19:901-14.

6. Vallinoto ACR, Ishak R. HTLV-2: an ancient infection among Indian people of Brazilian Amazon region. Rev Pan-Amaz Saude. 2017:8:7-9.

7. Ishak R, Vallinoto AC, Azevedo VN, Lewis M, Hall WW, Guimaraes Ishak MO. Molecular evidence of mother-to-child transmission of HTLV-IIc in the Kararao Village (Kayapo) in the Amazon region of Brazil. Rev Soc Bras Med Trop. 2001;34:519-25.
8. Braco ILJ, de Sa KSG, Waqasi M, Queiroz MAF, da Silva ANR, CayresVallinoto IMV, et al. High prevalence of human T-lymphotropic virus 2 (HTLV-2) infection in villages of the Xikrin tribe (Kayapo), Brazilian Amazon region. BMC Infect Dis. 2019;19:459.

9. Ishak R, Vallinoto ACR, Azevedo VN, Vicente ACP, Hall WW, Ishak MOG. Molecular evidence for infection by HTLV-2 among individuals with negative serological screening tests for HTLV antibodies. Epidemiol Infect. 2007;135:604-9.

10. Indígenas do Brasil. Asurini do Xingu-Awaeté. https://brasil.antropos.org uk/ethnic...a/27-29-asurini-xingu-awaete.html. Accessed 3 Oct 2019.

11. Peter BM, Slatkin M. The effective founder effect in a spatially expanding population. Evolution. 2015;69:721-34.

12. Juyal G, Mondal M, Luisi P, Laayouni H, Sood A, Midha V, et al. Population and genomic lessons from genetic analysis of two Indian populations. Hum Genet. 2014;133:1273-87.

13. da Costa CA, Furtado KC, Ferreira Lde S, Almeida Dde S, Linhares Ada C, Ishak R, et al. Familial transmission of human T-cell lymphotrophic virus: silent dissemination of an emerging but neglected infection. PLoS Negl Trop Dis. 2013;7:e2272.

14. Povos indígenas no Brasil. Arawete. https://pib.socioambiental.org/pt/ Povo:Arawet\%C3\%A9. Accessed 3 Oct 2019.

15. Viveiros de Castro EB. Araweté: os deuses canibais. Rio de Janeiro: Jorge Zahar; 1986.

\section{Publisher's Note}

Springer Nature remains neutral with regard to jurisdictional claims in published maps and institutional affiliations.
Ready to submit your research? Choose BMC and benefit from:

- fast, convenient online submission

- thorough peer review by experienced researchers in your field

- rapid publication on acceptance

- support for research data, including large and complex data types

- gold Open Access which fosters wider collaboration and increased citations

- maximum visibility for your research: over $100 \mathrm{M}$ website views per year

At BMC, research is always in progress.

Learn more biomedcentral.com/submissions 